\title{
sciendo
}

\section{Informal payments by patients in Croatia: benign custom or detrimental residue from socialism?}

\author{
Josip Franić \\ Institute of Public Finance, Zagreb, Croatia \\ josip.franic@ijf.hr \\ Anton Kojouharov \\ Center for the Study of Democracy, Sofia, Bulgaria \\ anton.kojouharov@csd.bg
}

\begin{abstract}
Almost three decades after the collapse of the socialist system, numerous informal practices inherited from that period have remained deeply entrenched in the Croatian economy and society. Faced with burdensome regulations and complicated procedures, many citizens and companies opt to resolve their problems using string-pulling, bribery and undeclared work. However, there are many other informal means of conduct, which have not been given adequate attention so far. One of them is the practice of giving gratuity and gifts to medical practitioners for services that are already covered by health insurance, whose roots and the exact function are still not sufficiently understood. To start filling the gap, this paper explores which groups of citizens give out-of-pocket payments to doctors and nurses, as well as what motivates them to do so. The logistic regression analysis applied on data from the Special Eurobarometer Survey No 470, which was conducted in October 2017 on a stratified sample of 1,038 Croatians, reveals that these payments by no means represent a benevolent custom of expressing gratitude for healing. Even though a certain portion of citizens exercises this practice out of choice, informal payments more commonly occur following a direct request by medical staff or simply because the patient feels a pressure to do so. As revealed by the analysis, the majority of such transactions in Croatia highly resemble standard forms of bribery. In line with this, it is recipients rather than donors of gifts and cash supplements who should be targeted in endeavours to eradicate the phenomenon.
\end{abstract}

Keywords: corruption, Croatia, healthcare, informal patient payments, logistic regression, out-of-pocket payments.

JEL classification: D73, 112, 118, P36.

DOI: $10.2478 /$ crebss-2019-0011

Received: September 29, 2019

Accepted: November 27, 2019 


\section{Introduction}

During the last decade of the twentieth century Croatia has witnessed flourishing of various informal practices inherited from the turbulent socialist period (Čučković, 2002, Ott, 2002, Bejaković, 2009). Contrary to the prevalent belief that these misconducts would lose their momentum once the country finished economic and cultural transition, most forms of illegitimate behaviour have remained deeply embedded in business and social interactions of Croatian citizens (Goel, Budak, Rajh, 2012, Bejaković, Williams, 2017, Franic, Williams, 2017, Franic, 2019). Vast and inefficient public administration, the weak rule of law and prevalent distrust in the state institutions seem to have paved the way for clandestine transactions to became a standard mode of operating in this South-East European country (Bejaković, 2009, Baric, Williams, 2013, Franic, Williams, 2017).

Informal supplementary payments by patients to doctors and nurses are certainly not an exception in this regard (Budak, Rajh, 2014, European Commission, 2017a, $2017 b)$. Also known as under-the-table payments, out-of-pocket payments, envelope payments and under-the-counter payments (Cherecheş, Ungureanu, Rus, Baba, 2011), this particular practice connotes all forms of "a direct contribution, which is made in addition to any contribution determined by the terms of entitlement, in cash or in kind, by patients or others acting on their behalf, to health care providers for services that the patients are entitled to" (Gaal, Belli, McKee, Szócska, 2006, p. 276). Although being somewhat less pervasive compared to other post-socialist countries, gifts and cash supplements given prior or after receiving treatment in public healthcare institutions severely undermine efficiency and fairness of the Croatian healthcare system (European Commission, 2017a, 2017b).

However, it is hard to expect any success in the fight against this practice without detailed insight into the mechanisms underlying its existence. No study has evaluated this matter so far, and therefore here we seek to address precisely this gap. Specifically, the idea is to explore why some Croatians spend additional financial resources for services that are already paid and in which circumstances these transactions usually happen. In line with this, the article is expected to have both theoretical and practical contribution. Alongside advancing our knowledge about the causes and nature of informal patient payments in Croatia, the findings presented here will also signalise to the authorities which policy responses could yield best results.

To achieve the above-mentioned objectives, the next section summarises the most important findings on this phenomenon from other countries around the world. This is followed by a short overview of the literature on Croatia and discussion about the research hypotheses which are tested in this paper. Section 4 then explains the methodology applied to do so, while Section 5 provides the results of the undertaken analysis. The last part of the paper brings concluding remarks.

\section{Why do people pay for medical services which are supposed to be free?}

Unlike other contacts with public servants, those in healthcare institutions are frequently life-important matters. Since the quality and speed of services received in hospitals can significantly affect one's well-being, many societies have developed a benevolent custom of expressing thankfulness to doctors and nurses in the form of gifts and/or tips (Gaal, McKee, 2005, Gaal et al., 2006, Cockcroft et al., 2008, Cohen, 2012). In point of fact, this tradition has been evidenced in all but few countries around the world, irrespective of their level of development (Pavlova et al., 2010, Cohen, 2012, 
European Commission, 2014, Williams, Horodnic, 2017).

Nonetheless, in some societies it gradually evolved into a harmful economic practice, which slows down the provision of healthcare services and reduces trust in the system. This particularly applies to post-socialist countries of Europe and Asia, in which this transformation was already visible during the 1970s and 1980s (Lewis, 2000, Thompson, Witter, 2000, Gaal, McKee, 2005, Pavlova et al., 2010). Substantial economic difficulties which the Eastern Bloc faced at that time were above all reflected through shortages of goods, lower quality of services and frequent interruptions in supply. This forced citizens to seek alternative strategies for satisfying everyday needs, including but not limited solely to healthcare (Lewis, 2000, Thompson, Witter, 2000, Radin, 2009).

Alongside the scarcity of medical equipment and drugs, an additional problem during that period were inadequate salaries of healthcare practitioners. In such circumstances, out-of-pocket payments by patients eventually became a tacitly approved norm, namely they served as informal wage supplements for underpaid medical personnel (Lewis, 2000, Ensor, 2004, Cohen, 2012, Stan, 2012, Radin, 2016).

Yet, in numerous countries the scope of the problem grew out of control after the fall of socialist regimes. Besides additional reductions in the quality and availability of public services, the initial phase of transition was also characterised by severe expansion of various dishonest practices across all spheres of the economy. Many medical professionals hence seized the opportunity to abuse their monopolistic market position for private gain, which resulted in informal patient payments becoming more similar to standard forms of public sector corruption (Ensor, 2004, Radin, 2009, Pavlova et al., 2010). In the majority of post-socialist countries out-ofpocket payments had, therefore, become a must: great many gift/money givers were actually reluctant participants, led primarily by the fear of being denied/postponed treatment or receiving poorer service rather than by desire to express gratitude (Vian, Grybosk, Sinoimeri, Hall, 2006, Moldovan, Van de Walle, 2013).

The pervasiveness of the phenomenon was indeed evidenced by numerous surveys from that period. For instance, during the early 2000 s one-third of medical treatments in Romania entailed additional payment for services that were already covered by public health insurance (Lewis, 2007), while in Bulgaria and Albania this was the case in every fifth interaction (Lewis, 2007). The situation was even more worrying in postsoviet countries, where the recorded incidence of this practice during the late 1990s ranged from $31 \%$ in Latvia (Lewis, 2000), to $74 \%$ in the Russian Federation (Lewis, 2000) and $90 \%$ in Moldova (Lewis, 2007).

Recent studies on the matter indicate that informal patient payments have remained a constituent part of healthcare systems in most transition economies (Stepurko, Pavlova, Gryga, Groot, 2010, Williams, Horodnic, Horodnic, 2016, European Commission, 2017a, Williams, Horodnic, 2018). The resultant schemes are, however, highly divergent in terms of actors involved and their rationales for participation. That is to say, scholars interested in this phenomenon generally agree that nowadays every single act of giving a gift and/or money in these societies actually lies on a continuum between two extremes: mere expression of gratitude which is initiated strictly by a patient and extortion on the part of service providers (Radin, 2009, Farcasanu, 2010, Williams, Horodnic, 2017). 


\section{Informal patient payments in Croatia - an overview of available studies}

Croatia was not exempt from the developments described above. According to the first study on this issue, which was conducted in 1994 on a random sample of 443 adults from Zagreb and Split, 14.0\% of citizens engaged in the custom of buying a gift to healthcare personnel while $8.4 \%$ were giving cash supplements (Mastilica, Božikov, 1999). A similar study from 2002, which included individuals from the whole country, revealed that some $12 \%$ of those Croatians who had visited a doctor during the 12month period preceding the survey spent additional financial resources for services they were entitled to (see Lewis, 2007). This share was comparable with those in transition economies of Central Europe, although somewhat lower than in other countries from the Balkans (Lewis, 2007).

Only slight improvement in this respect was documented by the joint study of the Institute of Economics Zagreb and United Nations Office on Drugs and Crime from 2010 (see Budak, Rajh, 2014). This survey of 3,000 adults displayed that $8.3 \%$ of citizens who had contacts with medical practitioners over the preceding year gave in-cash or inkind contributions to doctors, while $6 \%$ of them had such experiences with nurses (Budak, Rajh, 2014). While supporting staff was commonly rewarded with food, beverages and other commodities of symbolic prices, doctors were given cash more often. More precisely, only one in eight informal payments to nurses involved cash, whereby every third payment to a doctor was strictly in cash (Budak, Rajh, 2014).

This matter was further evaluated by the Special Eurobarometer survey on corruption, which took place in all 28 EU member states. According to the first wave of the survey from winter $2013,2.57 \%$ of Croatians who had visited a public healthcare institution during the 12-month period before the interview were asked to give a gift/cash or did so out of choice (European Commission, 2014, Williams, Horodnic, 2017). However, this should be perceived as a lower boundary for the real incidence rate, not only owing to a non-negligible refusal rate. Explicitly, the survey was concerned solely with cash-in-hand payments and 'valuable' gifts, thus omitting petty non-monetary bestowals in the form of chocolates, coffee, bottles of inexpensive wine, etc. What is more, respondents were left to freely decide what is 'valuable' and what is not, given that no clear cut-off point was provided.

The same study was repeated in 2017, with some minor differences in the outcomes. Specifically, $3.6 \%$ of respondents admitted informal payments to medical practitioners in the form of cash or valuable gifts, while $1.7 \%$ of them refused to answer this question (European Commission, 2017a). It is hence more indicative to say that only $94.7 \%$ of study participants strictly denied any supplementary payments (European Commission, 2017a).

Exactly this latest survey will be a starting point for our analysis. As already mentioned, no study on the causes and nature of out-of-pocket payments has been conducted so far, which is the gap this paper seeks to fill. In addition to examining socio-economic and demographic aspects of the phenomenon, the main aim is, therefore, to understand what motives some citizens to pay for services that are meant to be free of direct charge. This brings us to the ultimate goal of this study, which is to evaluate whether informal payments by patients in Croatia could be scrutinised through the prism of good manners or whether they are nothing more than a harmful leftover from previous periods. This will be done by analysing where these activities stand in the continuum between the expression of gratitude and extortion. In other words, the following two hypotheses will be tested in the rest of this paper:

- Gratitude hypothesis: Informal payments in Croatia are a benign cultural 


\section{custom of expressing thankfulness for received care}

- Extortion hypothesis: Informal patient payments in Croatia mostly occur following a direct request by the service providers or due to the patient feeling pressure to do so

The next section provides a detailed description of the variables used and statistical methods applied to check which of these two hypotheses holds true in Croatia.

\section{Data and methods}

Conducted in October 2017, the Special Eurobarometer Survey No 470 enables a comprehensive insight into attitudes and experience of Europeans with bribery and related misconducts in public institutions. A stratified random sample of approximately 1,000 individuals above 15 years of age was selected in every EU member state using a multi-stage random procedure. In the first step, a range of sampling points were drawn from every regional administrative unit, which were stratified by type of area and individual unit. Initial household addresses in each of the sampling points were then randomly determined, while subsequent households were chosen using the standard random route procedure. Interviewees from the sampled households were selected following the closest birthday rule.

The survey covered different areas of public administration, but particular attention was paid to the healthcare system. Participants were first inquired if they had any visit to a public healthcare institution in the last twelve months. Those who answered positively were then asked the following question: "Apart from official fees did you have to give an extra payment or a valuable gift to a nurse or a doctor, or make a donation to the hospital?"

To evaluate what distinguishes individuals who gave a confirmative answer to this question from the rest of the sample, we apply logistic regression modelling (Cramer, 2003, Menard, 2002, Hosmer, Lemeshow, Sturdivant, 2013). If $P\left(Y_{i}=1\right)$ denotes the probability of giving a contribution in cash or in kind for individual $i$, then the accompanying logistic model can be written as follows:

$$
P\left(Y_{i}=1\right)=\frac{e^{\beta_{0}+\sum_{k=1}^{K} \beta_{k} X_{i k}}}{1+e^{\beta_{0}+\sum_{k=1}^{K} \beta_{k} x_{i k}}},
$$

where $X_{k}(k=1, \ldots, K)$ represents an explanatory variable exerting effect $\beta_{k}$ on the modelled probability, and $K$ stands for the total number of such variables.

The key variable used to evaluate the gratitude hypothesis is the one measuring attitude towards non-monetary bestowals of public officers. Explicitly, every survey participant was asked to what extent they find acceptable when someone gives a gift to a public servant in any sphere of public administration, whereby the following three options were offered: never acceptable, sometimes acceptable, and always acceptable. Small in-kind contributions are generally recognised as a benevolent occurrence in most cultures (Lewis, 2000, Vian et al., 2006, Moldovan, Pavlova et al., 2010, Stan, 2012, Van de Walle, 2013), and therefore a positive effect of this variable would imply that thankfulness indeed plays a vital role in the decision-making process of Croatian patients.

Besides this, the interviewees were also requested to express their opinion about direct cash payments to public servants, with the identical answers being offered as 
in the case of non-monetary contributions. Since under-the-table cash compensations are usually associated with bribery (Gaal, McKee, 2005, Stepurko, Pavlova, Gryga, Groot, 2013), this variable is also included in the model so as to see where informal patient payments stand in comparison with the standard forms of corruption.

Another feature essential for the evaluation of the first hypothesis is the financial situation of a patient. If informal payments are an expression of free will on the part of the giver, then it is expected that more affluent individuals will be more likely to reward service providers. As the survey did not contain any direct question about the personal wealth of a respondent, we use a proxy variable indicating whether they had difficulties paying bills during the analysed period. The following three options were offered: most of the time, from time to time, and almost never/never.

It is also important to inspect if the type of settlement in which an individual lives exerts any influence on their behaviour. As shown by studies from other countries, this practice is usually more widespread in smaller communities due to much stronger social ties among their inhabitants (see Williams et al., 2016, Williams, Horodnic, 2018). Informal payments in rural areas are hence more frequently a benign tool for strengthening those ties rather than an imposed behaviour. In line with this, if the logistic regression reveals that people from rural parts of Croatia have a higher inclination towards informal payments, this will suggest that gratitude hypothesis may indeed be valid.

Similar arguments also hold true in the case of gender, given that studies from around the world identified women as more common participants in this practice (Stepurko et al., 2015, Williams et al., 2016, Williams, Horodnic, 2018). This is explained by women not only placing more emphasis on social relations but also being more disposed to express their feelings (and gratefulness in particular). Significant effect of gender would, therefore, also support the gratitude hypothesis.

Turning to the extortion hypothesis, we use two covariates to evaluate its validity in croatia. The first and more important of them is a perception regarding the pervasiveness of bribery and abuse of power among healthcare practitioners. This is a binary variable designating whether or not a respondent believes that these two represent a significant obstacle in the functioning of the system. The second variable is a binary indicator for any direct experience with corruption in other public spheres (i.e. outside the healthcare system) during the last twelve months. A positive effect of these two covariates would signalise that the decision to give a gift and/or money to medical practitioners is more likely to be an outcome of one's expectations and/or previous negative experience rather than an expression of free will.

Finally, we also include respondents' age in the model, primarily as a control variable. A positive effect is expected in this case, not only owing to pre-capitalist origins of informal patient payments (as explained before) but also because older individuals are more likely to face serious health issues that require repeated treatments.

An exhaustive account of the explanatory variables used in logistic modelling and the exact coding of theirs is provided in Table 1. Before moving to the presentation of results, it ought to be stressed that this is by no means a complete list of factors that could help in explaining why some patients in Croatia reside on informal payments to medical practitioners, while others do not have such a habit. Indeed, there are many other socio-economic features that are known to affect the behaviour of people in this respect, with the level of education and marital status being the most important among them (see Arsenijevic, Pavlova, Groot, 2015, Williams, Horodnic, 2017, 2018). However, the inclusion of additional variables would only increase the number of model coefficients (and consequently undermine the robustness of analysis), while not being 
particularly helpful in testing our hypotheses. For that reason, the decision was made to include only the eight variables mentioned above in the final statistical model, although a wider depiction of the practice will be provided in a descriptive manner.

Table 1 An overview of the explanatory variables

\begin{tabular}{|c|c|c|c|}
\hline Variable name & Description & Coding & $\begin{array}{l}\text { Missing } \\
\text { values }\end{array}$ \\
\hline Gender & $\begin{array}{l}\text { A binary variable representing } \\
\text { the gender of a respondent }\end{array}$ & $\begin{array}{l}0 \text { - male; } \\
1 \text { - female }\end{array}$ & 0 \\
\hline Age & $\begin{array}{l}\text { An interval variable denoting the } \\
\text { exact age of an interviewed } \\
\text { individual }\end{array}$ & $\begin{array}{l}\text { Values designate the } \\
\text { exact age }\end{array}$ & 0 \\
\hline Type of community & $\begin{array}{l}\text { A categorical variable for the } \\
\text { type of the residence area in } \\
\text { which an interviewee lives }\end{array}$ & $\begin{array}{l}1 \text { - rural area/village; } \\
2 \text { - small/middle-sized } \\
\text { town; } \\
3 \text { - large town }\end{array}$ & 0 \\
\hline Financial difficulties & $\begin{array}{l}\text { A categorical variable } \\
\text { designating the frequency of } \\
\text { facing difficulties in paying bills }\end{array}$ & $\begin{array}{l}1 \text { - most of the time; } \\
2 \text { - from time to time; } \\
3 \text { - almost never/never }\end{array}$ & 5 \\
\hline $\begin{array}{l}\text { Tolerance towards } \\
\text { giving gifts to public } \\
\text { officials }\end{array}$ & $\begin{array}{l}\text { A categorical variable specifying } \\
\text { to what extent the respondent } \\
\text { finds it acceptable when } \\
\text { someone gives a gift to public } \\
\text { officials }\end{array}$ & $\begin{array}{l}1 \text { - never acceptable; } \\
2 \text { - sometimes } \\
\text { acceptable; } \\
3 \text { - always acceptable }\end{array}$ & 3 \\
\hline $\begin{array}{l}\text { Tolerance towards } \\
\text { giving money to } \\
\text { public officials }\end{array}$ & $\begin{array}{l}\text { A categorical variable specifying } \\
\text { to what extent the respondent } \\
\text { finds it acceptable when } \\
\text { someone gives money to public } \\
\text { officials }\end{array}$ & $\begin{array}{l}1 \text { - never acceptable; } \\
2 \text { - sometimes } \\
\text { acceptable; } \\
3 \text { - always acceptable }\end{array}$ & 6 \\
\hline $\begin{array}{l}\text { Experience with } \\
\text { bribery in other } \\
\text { public spheres }\end{array}$ & $\begin{array}{l}\text { A binary variable displaying } \\
\text { whether the respondent was } \\
\text { asked or expected by public } \\
\text { servants outside the healthcare } \\
\text { system to give a gift/extra money }\end{array}$ & $\begin{array}{l}0 \text { - no; } \\
1 \text { - yes }\end{array}$ & 0 \\
\hline $\begin{array}{l}\text { Perception of the } \\
\text { pervasiveness of } \\
\text { bribery in the } \\
\text { healthcare system }\end{array}$ & $\begin{array}{l}\text { A binary indicator designating } \\
\text { whether the respondents see } \\
\text { bribery and abuse of power as } \\
\text { widespread among healthcare } \\
\text { practitioners in Croatia }\end{array}$ & $\begin{array}{l}0 \text { - no; } \\
1-\text { yes }\end{array}$ & 0 \\
\hline
\end{tabular}

Source: Authors' own representation.

An additional justification for limiting the number of explanatory variables can be found in a non-negligible number of missing values in the modelled variable. While this problem was anticipated owing to the sensitivity of the researched matter, it had to be adequately addressed in order to obtain credible results. Given that the same issue was also encountered for some of the explanatory variables (see Table 1), multiple imputation procedure was employed so as to replace non-existent answers (see Rubin, 1987, van Buuren, 2007, Newman, 2014). Explicitly, fifty imputations were simulated for every missing value using the system of chained equations.

\section{Results}

An insight into socio-economic, demographic and spatial characteristics of the patients who utilise informal payments, which is provided in Table 2, represents a good 
starting point in our search for the mechanisms underlying this phenomenon in Croatia. As can be seen, out-of-pocket payments were most frequently admitted by people from Dalmatia (8.8\%), followed by residents of Lika and Banovina (7\%). However, one should be careful when making conclusions about the geographical dispersion of this practice due to rather high refusal rates in certain regions. This above all applies to the capital and its surroundings, given that the share of individuals failing to provide an exact answer in this part of the country was actually considerably above the share of those who answered positively. As a matter of fact, Zagreb witnessed the lowest denial rate (Table 2).

Table 2 Socio-economic, demographic and spatial characteristics of informal payers in Croatia, \% of population

\begin{tabular}{|c|c|c|c|c|}
\hline Variable & Categories & Yes & No & $\begin{array}{c}\text { Refusal/Do } \\
\text { not know }\end{array}$ \\
\hline \multirow{2}{*}{ Gender } & Female & 3.6 & 95.6 & 0.8 \\
\hline & Male & 3.4 & 93.5 & 3.1 \\
\hline \multirow{4}{*}{ Age } & $15-24$ & 0.0 & 100.0 & 0.0 \\
\hline & $25-39$ & 2.3 & 94.2 & 3.5 \\
\hline & $40-54$ & 3.0 & 94.7 & 2.3 \\
\hline & $55+$ & 5.3 & 93.7 & 1.0 \\
\hline \multirow{5}{*}{$\begin{array}{l}\text { Marital } \\
\text { status }\end{array}$} & (Re-) Married & 5.2 & 93.4 & 1.4 \\
\hline & Cohabiting & 1.4 & 94.3 & 4.3 \\
\hline & Single & 1.1 & 98.1 & 0.8 \\
\hline & Divorced & 0.0 & 91.3 & 8.7 \\
\hline & Widowed & 2.5 & 96.8 & 0.7 \\
\hline \multirow{3}{*}{$\begin{array}{l}\text { Highest } \\
\text { educa. } \\
\text { Attained }\end{array}$} & No formal education/Still studying & 0.0 & 100.0 & 0.0 \\
\hline & Elementary/High school & 3.5 & 94.9 & 1.6 \\
\hline & University degree and higher & 4.4 & 92.1 & 3.5 \\
\hline \multirow{4}{*}{ Occup. } & \multirow{4}{*}{$\begin{array}{l}\text { Employed/Self-employed } \\
\text { Unemployed } \\
\text { Inactive (house persons, students, } \\
\text { etc.) } \\
\text { Retired }\end{array}$} & 2.3 & 95.3 & 2.4 \\
\hline & & 4.2 & 91.3 & 4.5 \\
\hline & & 1.4 & 98.6 & 0.0 \\
\hline & & 5.5 & 93.7 & 0.8 \\
\hline \multirow{6}{*}{ Region } & Zagreb and surrounding & 3.6 & 90.5 & 5.9 \\
\hline & North Croatia & 4.5 & 94.7 & 0.8 \\
\hline & Slavonia & 0.5 & 99.5 & 0.0 \\
\hline & Lika and Banovina & 7.0 & 93.0 & 0.0 \\
\hline & Istra, Rijeka and Gorski Kotar & 2.7 & 97.3 & 0.0 \\
\hline & Dalmatia & 8.8 & 91.2 & 0.0 \\
\hline \multicolumn{2}{|r|}{ Total } & 3.6 & 94.7 & 1.7 \\
\hline
\end{tabular}

Source: Authors' own work based on the Special Eurobarometer 470/Wave EB88.2.

Turning to the demographic features of the payers, there seems not to exist a substantial difference between genders in this respect. Although women were more likely to admit such behaviour (3.6\% compared to $3.4 \%$ for men), this does not necessarily imply they indeed participate more frequently. Owing to the unequal dispersion of missing values between these two groups, we prolong the discussion about the exact role of gender to the part of the text which presents results of statistical modelling.

Results are, however, more apparent when it comes to the role of age. Not only are the oldest citizens most inclined to give valuable gifts and money to medical practitioners in Croatia (5.3\%), but they also expressed the highest readiness to answer 
this question in the first place (i.e. refusal rate was only 1\%). The opposite is true for individuals below 40 years of age, given that only $2.3 \%$ of them answered positively, while $3.5 \%$ did not give an exact answer (Table 2). Interestingly, all individuals aged 24 and less denied giving gifts/money to medical staff, which is in line with the previously stated assumption. This particular issue will also be discussed later in more detail, after presenting the results of logistic regression.

In any case, the importance of age can be further grasped from the occupational structure of informal payers. As can be seen from Table 2, retired individuals are most frequent actors in such transactions. Interestingly, the unemployed seem to be more likely to offer cash supplements and gifts than individuals having a job. In fact, the real participation rate for this particular group of citizens is probably much higher, given a rather high refusal rate.

Table 2 also reveals that married individuals are by far most inclined towards this practice. One in twenty respondents from this group admitted giving gifts and/or money during one of their latest encounters with medical practitioners, which is in line with the research findings from other transition economies (Williams et al., 2016, Williams, Horodnic, 2018). The same is also true for education, given that informal payments appear to be most common among highly educated individuals in Croatia.

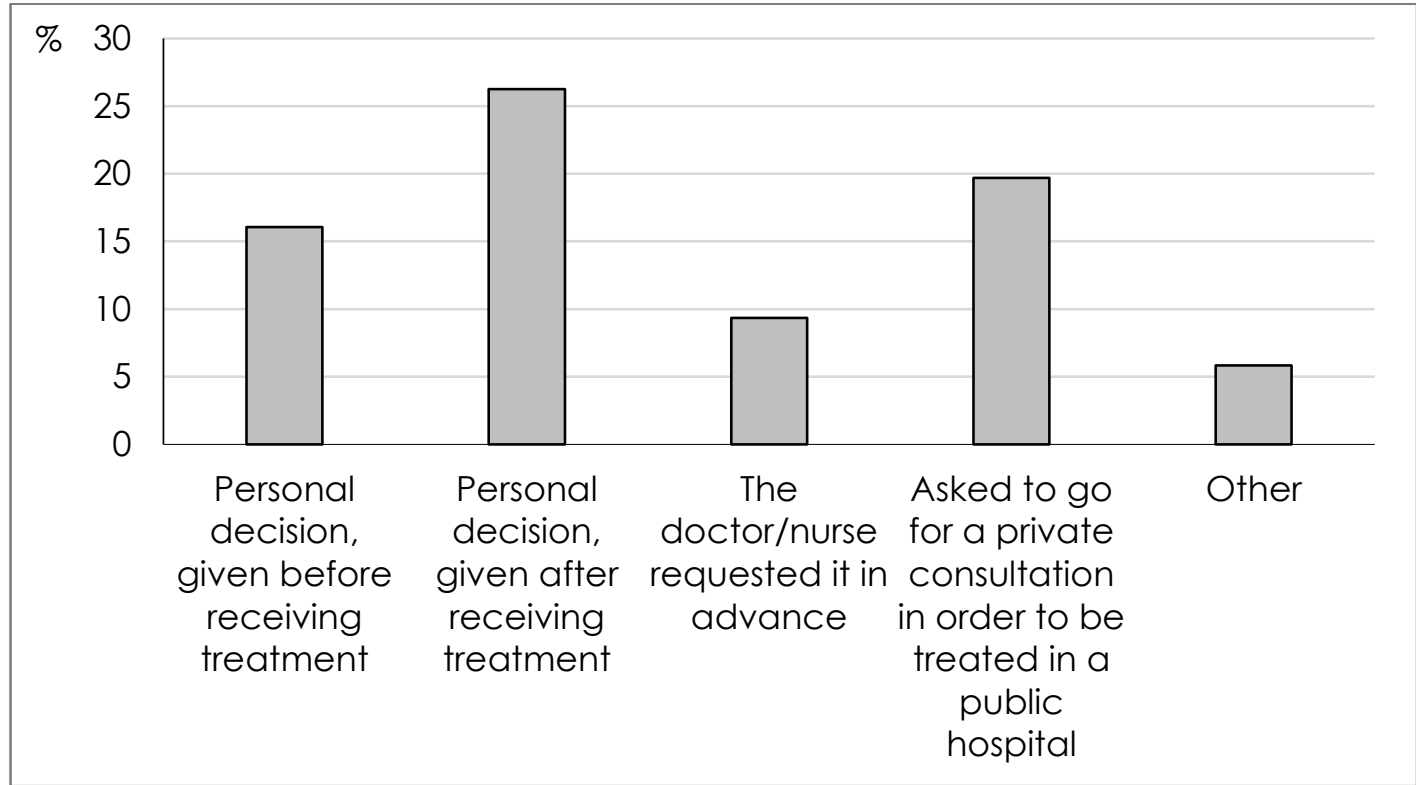

Figure 1 Reasons for giving informal supplements, \% of survey respondents admitting this practice

Source: Authors' own work based on the Special Eurobarometer 470/Wave EB88.2.

The next important thing to analyse is who usually initiates out-of-pocket payments and at what point they are done. Every individual admitting their involvement in this practice was offered six scenarios and asked to state which of them apply to their latest experiences. The results summarised in Figure 1 disclose that almost every tenth individual was requested material contribution by a doctor or nurse prior the treatment, while one in five was actually forced to spend additional money by being redirected to a private institution. These findings undoubtedly show that many medical professionals abuse their position for private gain, which indicates that the extortion hypothesis probably holds true in Croatia.

Nevertheless, informal payments are more often done on the initiative of a patient. As illustrated in Figure 1, every fourth case of additional material compensation was a 
personal decision of the service receiver, whereby the act happened after the treatment. Although slightly less frequent, prior-the-treatment exchanges are also quite common in Croatian healthcare. Explicitly, $16 \%$ of the citizens had at least one recent visit to healthcare professionals where they decided to play their cards in the very beginning.

Table 3 Determinants of informal payments by patients in Croatia, logistic regression results

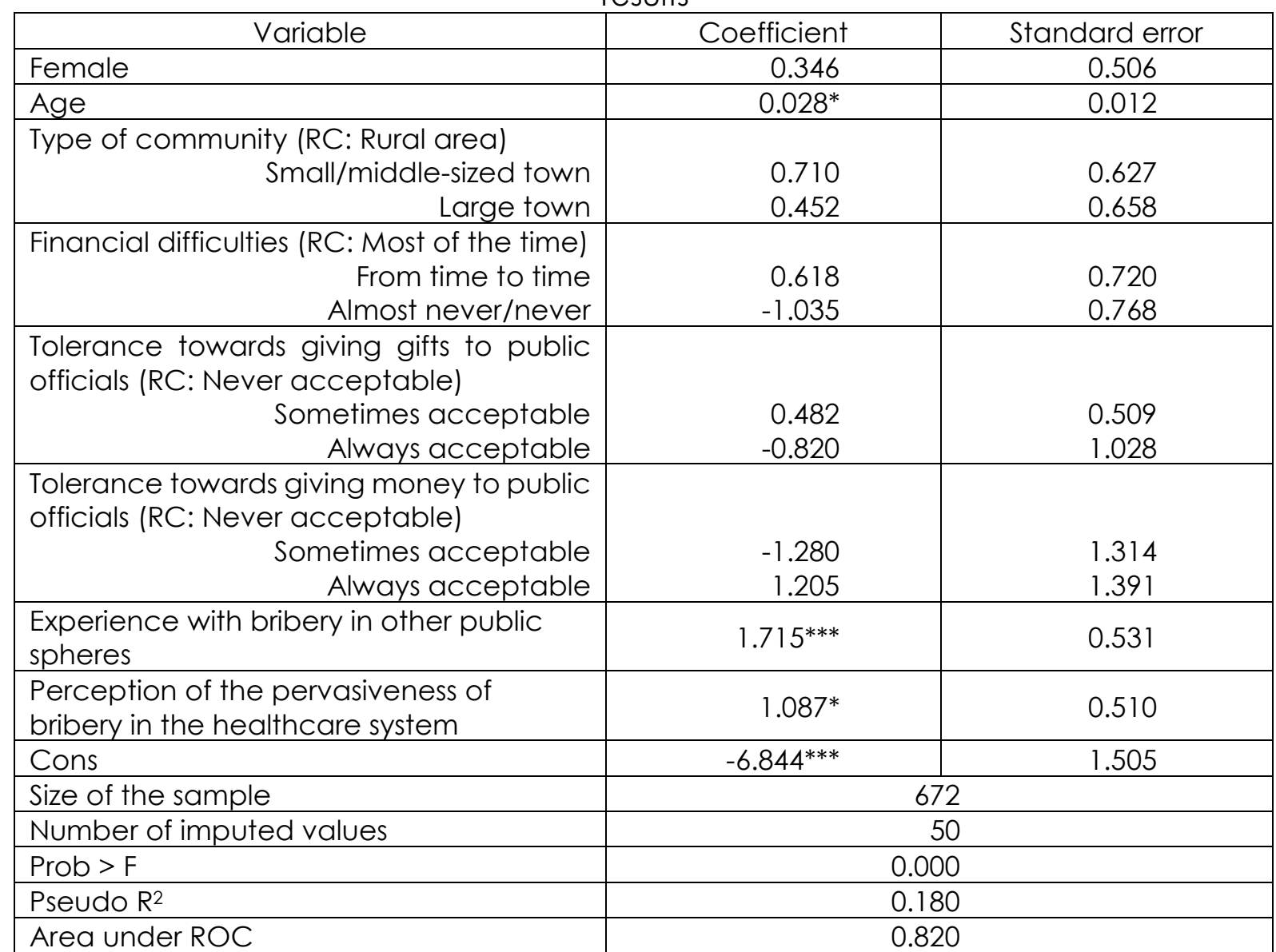

Note: ${ }^{*} p<0.05,{ }^{* *} p<0.01,{ }^{* * *} p<0.001$

Source: Authors' own work based on the Special Eurobarometer 470/Wave EB88.2.

Yet, logistic regression on the determinants of patient behaviour reveals that this voluntarism is more often a result of external pressure rather than a mere desire to express gratitude. As can be seen from Table 3, individuals who think that corruption is a severe problem in public healthcare institutions are statistically more likely to rely on informal payments than those who do not share this opinion. This would suggest that many of Croatians who give gifts or gratuity on their own most probably do it out of a belief that the service providers expect additional compensation.

This notion is further reinforced by the findings on the association between direct experience with corruption in other public institutions and one's propensity to reward medical staff. Explicitly, citizens who were recently asked by a public servant outside the healthcare to give a gift or extra money are statistically more likely to find themselves in the same situation when interacting with medical practitioners. These results, therefore, challenge the idea of out-of-pocket payments to doctors and nurses being a free choice on the part of a giver.

Indeed, we did not find any evidence supporting the gratitude hypothesis. Most 
importantly, no significant link was found between one's tolerance towards giving gifts and their propensity to do so prior or after the contact with doctors and nurses (Table 3). In fact, individuals justifying such behaviour in any circumstance appear to be less likely to utilise out-of-pocket payments compared to those who are entirely against gift rewards. However, the resulting coefficient is not significant, and the same holds true for the coefficient measuring whether the attitude towards cash payments exert any influence in this respect. These findings, therefore, show that supplementary payments in Croatia cannot generally be seen as a benign custom of expressing thankfulness for healing.

A further argument against the gratitude hypothesis can be found in the complete absence of any link between the financial situation of a patient and their likelihood to employ informal payments. As a matter of fact, citizens who never face financial difficulties seem to have a lower predisposition for giving gratuity and gifts than those who are struggling to have their ends meet, although the accompanying coefficient is not significant (Table 3). As well, we found no statistical evidence for this practice being more likely to occur in smaller communities nor among women. These findings hence refute the idea of informal patient payments in Croatia serving the role of social glve.

Finally, logistic regression highlighted the age of a patient as one of the central factors driving their behaviour. The older an individual is, the higher their propensity to give gratuity or gift is. Younger individuals, on the other hand, do not mind rewarding medical practitioners for the services which they had already paid through compulsory health insurance.

\section{Discussion and conclusion}

Akin to their counterparts from other post-socialist countries, many patients in Croatia engage in additional out-of-pocket payments to medical staff for the services they are entitled to by legislation. To understand why this is happening, this paper sought to identify key factors underlying the decision-making process of citizens in this regard. As revealed by a broader insight into the socio-economic and demographic peculiarities of the actors involved, informal payments are more common among highly educated individuals, and particularly among married ones. On the other hand, no significant discrepancies between genders nor between inhabitants from different types of settlements (i.e. rural areas; small and mid-size towns; and large cities) were found.

In fact, it is actually age what mostly distinguishes informal payers from the rest of the population. The practice persists mainly among older population cohorts, while younger citizens seldom show this form of misbehaviour. An optimistic explanation for this would be that younger generations either have been abandoning this detrimental practice or have never accepted it in the first place. If true, this would suggest that out-of-pocket payments by Croatian patients are only a leftover from the socialist period, which will lose its momentum in the future. Nonetheless, it is more plausible that gifts and envelopes are reserved for treatments of severe health conditions, which are more frequently encountered in the case of older citizens. Faced with a lifethreatening condition on the one hand, and numerous obstacles in their struggle to overcome it on the other (long waiting lists, unmotivated medical professionals, low quality of services received, etc.), many citizens are presumably ready to do whatever is needed so as to speed up the process. However, although it sounds quite reasonable, the validity of this latter theory cannot be tested with available data. More research into this matter is therefore needed. 
Whatever the case might be, many service providers in Croatia undoubtedly abuse their position for personal gain. As exposed by our analysis, lots of patients open their pursers either following a direct request by medical staff or due to feeling that the other side expects under-the-table contribution. Many cases of informal patient payments to doctors and nurses in Croatia hence highly resemble standard forms of public sector bribery.

In line with this, it is receivers, not the givers of informal payments who should be targeted in the efforts to eradicate the phenomenon. Besides putting additional emphasis on this issue during their education, the authorities should also seek effective mechanisms for identifying and punishing medical staff who request any unofficial contribution from patients or accept donations above the prescribed value. Yet, more tangible salary increases could also help, since this would undoubtedly reduce the motivation of doctors and nurses to seek additional sources of income.

Several notes of caution are, however, necessary at this point. First of all, even though the two waves of the Special Eurobarometer survey indicated a moderate decline in the occurrence of informal patient payments compared to previous periods, this does not necessarily mean that nowadays fewer patients bring plastic or paper bags to the public healthcare institutions. Many survey respondents most likely did not bother to report a bottle of wine or a box of chocolates, as they were strictly asked about 'valuable gifts' (however interpreted). As a result, the real incident rate of this phenomenon in Croatia is certainly much larger than suggested by the survey.

Yet, even if this particular form of misbehaviour was indeed gradually vanishing from society, this would not automatically imply an overall drop of illegitimate practices and abuse of power in Croatian healthcare. In fact, service providers and patients represent only the final loops in the perplex chain of stakeholders within this complex system. There are many other actors securing the smooth operation of public healthcare, with the most important among them being drug suppliers, producers of medical equipment, private insurance agencies and public healthcare fund. Mutual interactions of these stakeholders hence make the public healthcare system a fruitful field for various forms of illicit behaviour.

Actually, it would even be inappropriate to conclude that patients themselves are generally becoming less prone to circumventing rules and procedures. There are many other types of fraudulent activities which go beyond contribution in kind or in cash to the medical staff with whom they directly interact. Most notable such misconducts include discretionary envelope payments to other gate-keepers and pulling strings to achieve advantages over remaining patients. Unfortunately, not much is known about the pervasiveness and nature of these alternative strategies used by citizens to outsmart the system. If this paper thus motivates other researchers to further explore the behaviour of Croatian patients, then it will have fulfilled its broader aim.

\section{References}

1. Arsenijevic, J., Pavlova, M., Groot, W. (2015). Out-of-pocket payments for health care in Serbia. Health Policy. Vol. 119, No. 10, pp. 1366-1374.

2. Baric, M., Williams, C. C. (2013). Tackling the undeclared economy in Croatia. South-Eastern Europe Journal of Economics, Vol. 1, pp. 7-36.

3. Bejaković, P. (2009). Tax evasion, state capacity and trust in transitional countries: the case of Croatia. Društvena istraživanja: časopis za opća društvena pitanja, Vol. 18, No. 4-5, pp. 102-103.

4. Bejaković, P., Williams, C. C. (2017). Undeclared economic activities of Croatian companies: findings from a representative survey of 521 companies. GREY Working Paper No. 13. 
Sheffield University Management School, Sheffield. Avaliable at https://doi.org/10.13140/RG.2.2.14888.26883 [17 October 2019].

5. Budak, J., Rajh, E. (2014). Korupcija u zdravstvu u Hrvatskoj: mit ili stvarnost? [Corruption in the Croatian health system: myth or reality?], In O Zdravstvu iz ekonomske perspektive. Vehovec, M. (ed.), Ekonomski institut, Zagreb, pp. 247-270.

6. Cherecheş, R., Ungureanu, M., Rus, I., Baba, C. (2011). Informal payments in the health care system - research, media and policy. Transylvanian Review of Administrative Science, Vol. 32, pp. 5-14.

7. Cockcroft, A., Andersson, N., Paredes-Solís, S., Caldwell, D., Mitchell, S., Milne, D., Merhi, S., Roche, M., Konceviciute, E., Ledogar, R. J. (2008). An inter-country comparison of unofficial payments: Results of a health sector social audit in the Baltic States. BMC Health Services Research. Vol. 8. No. 15, pp. 1-12.

8. Cohen, N. (2012). Informal payments for health care - the phenomenon and its context. Health Economics, Policy and Law. Vol. 7, No. 3, pp. 285-308.

9. Cramer, J. S. (2003). Logit models from economics and other fields, Cambridge University Press, New York.

10.Čučković, N. (2002). Siva ekonomija i proces privatizacije u Hrvatskoj, 1997-2001 [The grey economy and the privatisation process in Croatia, 1997-2001]. Financijska Teorija i Praksa. Vol. 26, No. 1, pp. 245-271.

11.Ensor, T. (2004). Informal payments for health care in transition economies, Social Science and Medicine, Vol. 58, No. 2, pp. 237-246.

12.European Commission (2014). Special Eurobarometer 397. Corruption. European Commission, Directorate-General for Home Affairs, Brussels. Available at https://doi.org/10.1016/S0015-6264(73)80341-4 [17 October 2019].

13.European Commission (2017a). Special Eurobarometer 470. Corruption. European Commission, Directorate-General for Migration and Home Affairs, Brussels. Available at http://ec.europa.eu/commfrontoffice/publicopinion/index.cfm/ResultDoc/download/Doc umentKy/81007 [17 October 2019].

14.European Commission (2017b). Updated study on corruption in the healthcare sector. Publications Office of the European Union, Luxembourg. Available at https://doi.org/10.2837/68580 [17 October 2019].

15.Farcasanu, D. O. (2010). Population perception on corruption, informal payments and introduction of co-payments in the public health system in Romania. Management in Health. Vol. xiv, No. 1, pp. 8-13.

16.Franic, J. (2019). Undeclared economy in Croatia during the 2004-2017 period: Quarterly estimates using the MIMIC method. Croatian Economic Survey, Vol. 21, No. 1, pp. 5-46.

17.Franic, J., Williams, C. C. (2017). Illegitimate economic practices in Croatia, Findings from a representative survey of 2,000 citizens. GREY Working Paper No. 9. Sheffield University Management School, Sheffield. Available at https://doi.org/10.2139/ssrn.2932315 [17 October 2019].

18.Gaal, P., Belli, P. C., McKee, M., Szócska, M. (2006). Informal payments for health care: definitions, distinctions, and dilemmas. Journal of Health Politics, Policy and Law, Vol. 3, No. 2, pp. 251-293.

19. Gaal, P., McKee, M. (2005). Fee-for-service or donation? Hungarian perspectives on informal payment for health care. Social Science and Medicine, Vol. 60, No. 7, pp. 1445-1457.

20.Goel, R. K., Budak, J., Rajh, E. (2012). Factors driving bribe payments: survey evidence from Croatia, Transition Studies Review. Vol. 19, No. 1, pp. 13-22.

21.Hosmer, D. W., Lemeshow, S., Sturdivant, R. X. (2013). Applied logistic regression. John Wiley \& Sons, Inc, New Jersey.

22.Lewis, M. (2000). Who is paying for health care in Eastern Europe and Central Asia? The World Bank, Washington, D.C. Available at https://doi.org/10.2139/ssrn.1457795 [17 October 2019].

23.Lewis, M. (2007). Informal payments and the financing of health care in developing and transition countries, Health Affairs. Vol. 26, No. 4, pp. 984-997.

24.Mastilica, M., Božikov, J. (1999). Out-of-pocket payments for health care in Croatia: implications for equity. Croatian Medical Journal, Vol. 40, No. 2, pp. 152-159.

25.Menard, S. (2002). Applied logistic regression analysis (2nd ed.). SAGE Publications, Inc, 
Thousand Oaks.

26.Meskarpour-Amiri, M., Arani, A. A., Sadeghi, H., Agheli-Kohnehshahri, L. (2016). Socioeconomic factors affecting informal payments in the health sector. Transylvanian Review of Administrative Sciences, Vol. 47, pp. 116-128.

27.Moldovan, A., Van de Walle, S. (2013). Gifts or bribes? Attitudes on informal payments in Romanian health care. Public Integrity, Vol. 15, No. 4, pp. 383-399.

28. Newman, D. A. (2014). Missing data: five practical guidelines. Organizational Research Methods, Vol. 17, No. 4, pp. 372-411.

29. Ott, K. (2002). Neslužbeno gospodarstvo u Republici Hrvatskoj 1990-2000 [Informal economy in Croatia during the period 1990-2000]. Financijska Teorija i Praksa, Vol. 26, No. 1, pp. 1-30.

30.Pavlova, M., Stepurko, T., Gordeev, V. S., Tomini, S., Gryga, I., Groot, W. (2010). Informal patient payments for health care services: policy challenges and solutions. Zdrowie Publiczne i Zarzadzanie, Vol. 8, No. 1, pp. 5-11.

31.Radin, D. (2009). Too ill to find the cure? Corruption, institutions, and health care sector performance in the new democracies of Central and Eastern Europe and former Soviet Union. East European Politics and Societies, Vol. 23, No. 1, pp. 105-125.

32.Radin, D. (2016). Why health care corruption needs a new approach. Journal of Health Services Research and Policy, Vol. 21, No. 3, pp. 212-214.

33. Rubin, D. B. (1987). Multiple imputation for nonresponse in surveys. John Wiley \& Sons, Inc, New York.

34.Stan, S. (2012). Neither commodities nor gifts: Post-socialist informal exchanges in the Romanian healthcare system. Journal of the Royal Anthropological Institute, Vol. 18, No. 1, pp. 65-82.

35.Stepurko, T., Pavlova, M., Gryga, I., Groot, W. (2010). Empirical studies on informal patient payments for health care services: a systematic and critical review of research methods and instruments, BMC Health Services Research. Vol. 10, No. 273, pp. 1-13.

36.Stepurko, T., Pavlova, M., Gryga, I., Groot, W. (2013). Informal payments for health care services - Corruption or gratitude? A study on public attitudes, perceptions and opinions in six Central and Eastern European countries, Communist and Post-Communist Studies. Vol. 46, No. 4, pp. 419-431.

37.Stepurko, T., Pavlova, M., Gryga, I., Groot, W. (2015). To pay or not to pay? A multicountry study on informal payments for health-care services and consumers' perceptions. Health Expectations, Vol. 18, No. 6, pp. 2978-2993.

38.Thompson, R., Witter, S. (2000). Informal payments in transitional economies: Implications for health sector reform. International Journal of Health Planning and Management, Vol. 15, pp. 169-187.

39.Van Buuren, S. (2007). Multiple imputation of discrete and continuous data by fully conditional specification. Statistical Methods in Medical Research, Vol. 16, pp. 219-242.

40.Vian, T., Grybosk, K., Sinoimeri, Z., Hall, R. (2006). Informal payments in government health facilities in Albania: Results of a qualitative study. Social Science and Medicine, Vol. 62, No. 4, pp. 877-887.

41.Williams, C. C., Horodnic, I., Horodnic, A. (2016). Who is making informal payments for public healthcare in East-Central Europe? An evaluation of socio-economic and spatial variations. Eastern Journal of European Studies, Vol. 7, No. 1, pp. 49-61.

42.Williams, C. C., Horodnic, A. V. (2017). Rethinking informal payments by patients in Europe: An institutional approach. Health Policy, Vol. 121, No. 10, pp. 1053-1062.

43.Williams, C. C., Horodnic, A. V. (2018). Explaining informal payments for health services in Central and Eastern Europe: an institutional asymmetry perspective. Post-Communist Economies, Vol. 30, No. 4, pp. 440-458. 


\section{About the authors}

Josip Franić, PhD, is Research Associate at the Institute of Public Finance, Zagreb, Croatia. From 2013 to 2015, he worked as a Marie Curie Research Fellow at the Sheffield University Management School, United Kingdom. His research interests relate to the economics of labour, with primary emphasis on the issue of informal work and other forms of income tax evasion. At present, he is a member of the international research team providing analytical support to the European Platform Tackling Undeclared Work. The author can be contacted at josip.franic@ijf.hr.

Anton Kojouharov is an Analyst at the Centre for the Study of Democracy in Bulgaria. His current work focuses on informal employment, money laundering, financial crime and organised crime. During 2014 and 2015 he worked as a Marie Curie Researcher Fellow at the Sheffield University Management School, United Kingdom, within the FP7 research project focused on building capacities and capabilities for tackling undeclared work in Bulgaria, Croatia and North Macedonia. The author can be contacted at anton.kojouharov@csd.bg. 